\title{
Purification and characterization of an antibacterial protein from dried fruiting bodies of the wild mushroom Clitocybe sinopica
}

\author{
Suyue Zheng ${ }^{1,2}$, Qinghong Liu', Guoqing Zhang ${ }^{1}$, Hexiang Wang ${ }^{1 凶}$ and Tzi Bun Ng ${ }^{3 凶}$ \\ 1State Key Laboratory for Agrobiotechnology and Department of Microbiology, China Agricultural University, Beiijing, China; ${ }^{2 H e b e i ~ E n g i n e e r i n g ~}$ \\ University, Handan, China; ${ }^{3 S}$ chool of Biomedical Sciences, Faculty of Medicine, The Chinese University of Hong Kong, Shatin, New Territories, \\ Hong Kong, China
}

A novel antibacterial protein with a molecular mass of $44 \mathrm{kDa}$ has been isolated from dried fruiting bodies of the wild mushroom Clitocybe sinopica. Sodium dodecyl sulfate/polyacrylamide gel electrophoresis showed that the protein was composed of two subunits each with a molecular mass of $22 \mathrm{kDa}$. Its $\mathrm{N}$-terminal amino-acid sequence, SVQATVNGDKML, has not been reported for other antimicrobial proteins. The purification protocol included ion exchange chromatography on DEAE-cellulose, CM-cellulose and Q-Sepharose, and gel filtration by fast protein liquid chromatography on Superdex 75 . The antibacterial protein was adsorbed on all three ion exchangers. The antimicrobial activity profile of the protein against tested bacterial and fungal strains disclosed that it possessed potent antibacterial activity against Agrobacterium rhizogenes, A. tumefaciens, A. vitis, Xanthomonas oryzae and $X$. malvacearum with a minimum inhibitory concentration mostly below $0.6 \mu \mathrm{M}$. However, it had no antibacterial activity against Pseudomonas batatae, Erwinia herbicola, Escherichia coli, and Staphylococcus aureus, and no antifungal activity against Setosphaeria turcica, Fusarium oxysporum, Verticillium dahliae, Bipolaris maydis, and B. sativum. The antibacterial antivity against $A$. tumefaciens was stable after exposure to $20-60^{\circ} \mathrm{C}$ for $30 \mathrm{~min}$ and to $\mathrm{pH} \mathrm{4-9}$ for $1 \mathrm{~h}$.

Keywords: mushroom, fruiting bodies, antibacterial protein, Clitocybe sinopica

Received: 01 August, 2009; revised: 12 January, 2010; accepted: 31 January, 2010; available on-line: 02 March, 2010

\section{INTRODUCTION}

Mushrooms have long been appreciated for their flavor and texture. They need to produce antibacterial and antifungal compounds in order to survive in their natural environment. It is therefore not surprising that antimicrobial compounds could be isolated from many mushrooms (Lindequist et al., 2005). Antimicrobial proteins (AMPs), as important antibacterial and antifungal compounds, have attracted attention of a large number of investigators.

AMPs are largely distributed among living organisms including plants, animals, fungi and some single-celled microorganisms (Jenssen, 2005). AMPs, which directly interfere with the growth, multiplication and spread of microbial organisms and permit plants and animals to resist infection by environmental microbes, represent important components of the defense system (Lehrer
\& Ganz, 1999). To date, different proteins with antibacterial or antifungal activity have been reported. Most of these proteins were isolated from animals (Steiner et al., 1981; Lemaitre et al., 1996; Destoumieux et al., 1997; Krishnakumari \& Nagaraj, 1997; Torres-Larios et al., 2000), plants (Huynh et al., 1992; Cammue et al., 1995; Talas, 2004) and bacteria (Barja et al., 1989; James et al., 1996; Longeon et al., 2004). Only few of them came from fungi (Mygind et al., 2005; Hu et al., 2006), especially macrofungi.

Antifungal peptides and proteins have been isolated from the fungi Aspergillus giganteus (Lacadena et al., 1995), A. niger (Lee et al., 1999), Zygosaccharomyces bailii (Weiler et al., 2003), Hypsizigus marmoreus (Lam \& Ng, 2001b), Pleurotus erygii (Wang \& $\mathrm{Ng}, 2004)$, Lyophyllum shimeji (Lam \& $\mathrm{Ng}, 2001 \mathrm{a}$ ), and Tricholoma giganteum (Guo et al., 2005). However, the literature pertaining to antibacterial peptides and proteins is scanty.

Clitocybe sinopica is a well-known wild edible mushroom species found in China. To the best of our knowledge, no research has been reported on the chemical composition and biological activities of $C$. sinopica extract. Therefore, the aim of the present work was to evaluate the antimicrobial potential of this mushroom extract on several phytopathogenic microorganisms.

\section{MATERIALS AND METHODS}

Materials. The fruiting bodies of the wild mushroom Clitocybe sinopica were collected from Heilongjiang province, in the northeast region of China. Fifteen bacterial pathogenic strains were used in this study: Agrobacterium rhizogenes (NL24-2, NL5-4, MG 12-1, HBT 6-1, SX073, NL12-2) A. vitis (MI3-2, MI23-1), A. tumefaciens (MG101), Xanthomonas oryzae, X. malvacearum, Psendomonas batatae, Erwinia berbicola, Escherichia coli and Staphylococcus aureus. Five fungal strains were also tested: Setosphaeria turcica, Bipolaris maydis, Fusarium oxysporum, Verticillium dabliae and Bipolaris sativum. All tested bacterial and fungal strains were obtained from the Department of Plant Pathology of the China Agriculture University (Beijing, China PR).

Isolation procedure. Dried fruiting bodies of $C$. sinopica were homogenized in $0.15 \mathrm{M} \mathrm{NaCl}$ at $4{ }^{\circ} \mathrm{C}$ overnight. The supernatant was centrifuged at $8000 \times g$

$\triangle$ e-mail: Tzi Bun Ng: b021770@mailserv.cuhk.edu.hk; Hexiang Wang: hxwang@cau.edu.cn

Abbreviations: AMP, antimicrobial proteins; cfu, colony-forming unit; FPLC, fast protein liquid chromatography; MIC, minimum inhibitory concentration. 
for $15 \mathrm{~min}$ before $\left(\mathrm{NH}_{4}\right)_{2} \mathrm{SO}_{4}$ was added to $80 \%$ saturation. The precipitate was collected by centrifugation at $8000 \times g$ for $15 \mathrm{~min}$ again. Then the precipitate was dissolved and dialyzed to remove $\left(\mathrm{NH}_{4}\right)_{2} \mathrm{SO}_{4}$ before ion exchange chromatography on a DEAE-cellulose (Sigma) column $(2.5 \mathrm{~cm} \times 20 \mathrm{~cm})$ in $10 \mathrm{mM}$ sodium phosphate buffer ( $\mathrm{pH} 7.5$ ). Unadsorbed proteins (fraction D1) were eluted with the buffer while bound ones were desorbed sequentially with $100 \mathrm{mM} \mathrm{NaCl}$, $200 \mathrm{mM} \mathrm{NaCl}$ and $1 \mathrm{M} \mathrm{NaCl}$ to form fractions D2, D3 and D4, respectively. Fraction D3 with antibacterial activity was dialyzed and then chromatographed on a column of CM-cellulose (Sigma) $(1.5 \times 20 \mathrm{~cm})$ in $10 \mathrm{mM}$ sodium phosphate buffer ( $\mathrm{pH}$ 6.2). After elution of unadsorbed proteins (CM1) with the same buffer, the bound fractions CM2, CM3 and CM4 were eluted with the same buffer containing $50 \mathrm{mM} \mathrm{NaCl}$, $150 \mathrm{mM} \mathrm{NaCl}$ and $1 \mathrm{M} \mathrm{NaCl}$, respectively. The active peak (CM3) was then subjected to ion exchange chromatography on a column of Q-Sepharose (GE Healthcare $(1 \mathrm{~cm} \times 10 \mathrm{~cm})$ in $10 \mathrm{mM}$ sodium phosphate buffer ( $\mathrm{pH}$ 6.5). After removal of unadsorbed protein (fraction Q1), the bound material was eluted with a linear $\mathrm{NaCl}$ concentration gradient $(0-500 \mathrm{mM})$ in the same buffer. The active fraction (Q2) was then gel-filtered on a Superdex 75 HR 10/30 column (GE Healthcare) by fast protein liquid chromatography (FPLC) in $0.2 \mathrm{M} \mathrm{NH}_{4} \mathrm{HCO}_{3}$ buffer ( $\mathrm{pH}$ 8.5) using an AKTA Purifier (GE Healthcare). Two peaks were obtained. The first peak (SU1) with antibacterial activity was subjected to sodium dodecyl sulfate-polyacrylamide gel electrophoresis (SDS/PAGE) which was conducted according to the method of Laemmli and Favre (1973). N-terminal sequencing was carried out using a Hewlett-Packard (HP) Edman degradation unit and an HP 1000 HPLC System.

Assay of antibacterial activity. The assay for antibacterial activity was conducted using sterile Petri plates $(90 \mathrm{~mm} \times 15 \mathrm{~mm})$ containing $15 \mathrm{ml}$ suitable medium agar $(1.8 \%$ agar). Five milliliters of warm nutrient agar $(0.7 \%)$ containing the bacterium were poured into the plates. A sterile blank paper disk (6.25 $\mathrm{mm}$ in diameter) or Oxford cup was placed on the agar. The antibacterial protein (40 $\mu \mathrm{l}$ of a $1 \mathrm{mg} / \mathrm{ml}$ solution) in $10 \mathrm{mM}$ sodium phosphate buffer ( $\mathrm{pH}$ 7.0) was added to one of the disks. Only sterile buffer was added to the control disk. The plate was incubated at $28^{\circ} \mathrm{C}$ for $24 \mathrm{~h}$. A transparent ring around the paper disk signifies antibacterial activity (Lam et al., 2000).

Assay of minimum inhibitory concentration (MIC). The MIC for each bacterial strain tested was measured by the liquid culture medium dilution method using Luria Bertani or modified 523 medium, depending on the strain. Nine hundred milliliters of medium were placed in a sterilized test tube to which $90 \mu \mathrm{l}$ of the tested sample and $10 \mu \mathrm{l}$ of the cultured bacterial solution (final bacterial count of $1 \times 10^{6} \mathrm{cfu} / \mathrm{ml}$ ) were added. The tube was cultured under suitable conditions. The minimum concentration of added samples in which no bacterial growth was observed was defined as the MIC (Hirasawa et al., 1999).

Assay of antifungal activity. The assay was conducted as detailed by Wang et al. (2004).

Test for thermostability and $\mathrm{pH}$ stability. The antibacterial protein was exposed to various temperatures ranging from $20^{\circ} \mathrm{C}$ to $80^{\circ} \mathrm{C}$ at $10^{\circ} \mathrm{C}$ intervals for $30 \mathrm{~min}$. After heat treatment, samples were centrifuged $(12000 \times g, 5 \mathrm{~min})$ and the supernatants were used for assay of antibacterial activity. The antibacterial activity of each sample was compared with that of a control treated at $4^{\circ} \mathrm{C}$ for $30 \mathrm{~min}$.

The test for $\mathrm{pH}$ stability was conducted as described above. The antibacterial protein was treated at various $\mathrm{pH}$ values from 3 to 9 for $1 \mathrm{~h}$.

Determination of ribonuclease activity. The activity of the antibacterial protein toward yeast tRNA was determined as described by Wang and Ng (1999).

Determination of haemagglutinating activity. The assay was conducted as described by Wang et al. (1996).

\section{RESULTS}

\section{Protein purification}

Antibacterial activity was located mainly in fraction D3 adsorbed on DEAE-cellulose which was eluted with $0.2 \mathrm{M} \mathrm{NaCl}$. The larger unadsorbed fraction D1 and other adsorbed fractions were devoid of antibacterial activity. D3 was fractionated on CM-cellulose into an unadsorbed fraction CM1 and three adsorbed fractions CM2, CM3, and CM4. Antibacterial activity resided in fraction CM3. Fraction CM3 was collected for further purification on a Q-Sepharose column. The activity was eluted with a linear gradient of $0-0.5 \mathrm{M} \mathrm{NaCl}$ in $10 \mathrm{mM}$ phosphate buffer ( $\mathrm{pH}$ 6.5). Two peaks were obtained. Antibacterial activity was detected in fraction Q2 (Fig. 1). Fraction Q2 was resolved on Superdex 75 into two fractions, SU1 and SU2 (Fig. 2). The first and larger fraction, SU1, was enriched in antibacterial activity. It demonstrated a molecular mass of $44 \mathrm{kDa}$ in gel filtration (Fig. 2) and $22 \mathrm{kDa}$ in SDS/PAGE (Fig. 3). Thus the antibacterial protein is most likely composed of two subunits with the same molecular mass of $22 \mathrm{kDa}$. The yields of the various chromatographic fractions are presented in Table 1. The N-terminal sequence of the protein, SVQATVNGDKML, is not found in any reported antimicrobial protein. It is dissimilar to those of previously isolated mushroom antimicrobial proteins ( $\mathrm{Ta}-$ ble 2).

\section{Assays of antimicrobial and other activities}

The antimicrobial activity of the isolated protein was tested against different bacterial and fungal strains. The antimicrobial activity was tested at the dose of $40 \mu \mathrm{g}$, it showed potent antimicrobial activity against most bacteria (Fig. 4). The minimal inhibitory concentration (MIC)

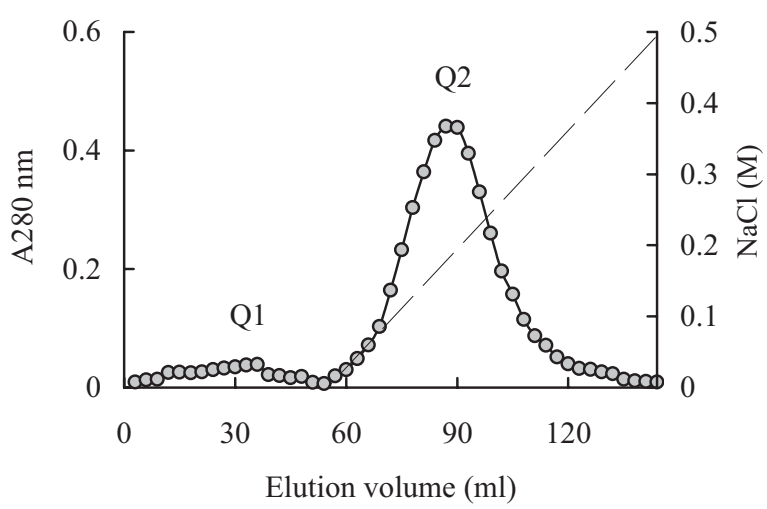

Figure 1. Cation exchange chromatography of fraction CM3 on Q-Sepharose

Starting buffer: $10 \mathrm{mM}$ sodium phosphate buffer ( $\mathrm{pH} 6.5$ ). 


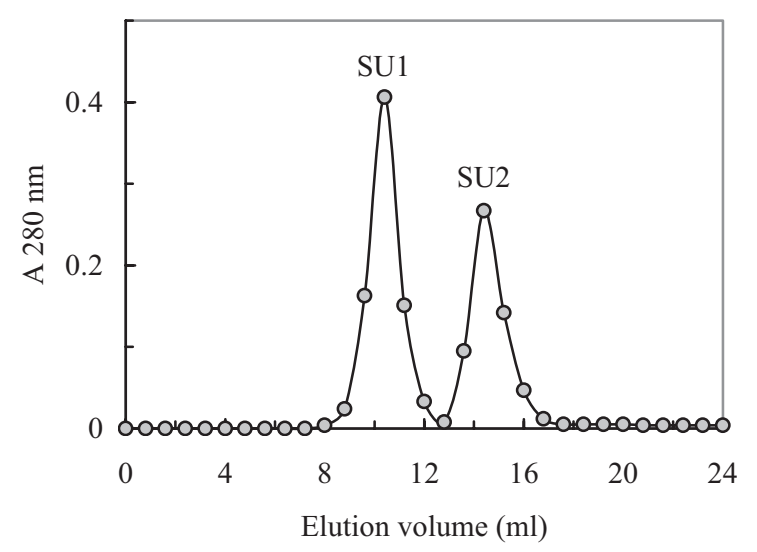

Figure 2. Gel filtration of Q2 on Superdex 75 HR10/30

The column had been calibrated with molecular mass markers from GE Healthcare including phosphorylase $b(94 \mathrm{kDa})$, bovine serum albumin $(67 \mathrm{kDa})$, ovalbumin $(43 \mathrm{kDa})$, carbonic anhydrase $(30 \mathrm{kDa})$, soybean trypsin inhibitor $(20 \mathrm{kDa})$ and $\alpha$-lactalbumin (14.4 kDa).

of the antibacterial protein toward different bacterial strains is presented in Table 3. However, antifungal, ribonuclease and hemagglutinating activities were not detected (not shown).

\section{Influence of $\mathrm{pH}$ and heat treatments}

Figure $5 \mathrm{~A}$ shows the antibacterial effects of the protein against Agrobacterium tumefaciens after exposure to 20 $80^{\circ} \mathrm{C}$ for $30 \mathrm{~min}$. The protein was heat-labile. Almost no change was observed in the antibacterial effect after heat treatment at $60^{\circ} \mathrm{C}$ for $30 \mathrm{~min}$. After exposure to $70^{\circ} \mathrm{C}$ for $30 \mathrm{~min}$, the antibacterial activity was reduced to $80 \%$. Following treatment at $80^{\circ} \mathrm{C}$ for $30 \mathrm{~min}$, the protein was completely inactivated.

Figure 5B shows the antibacterial effects of the protein against $A$. tumefaciens after exposure to $\mathrm{pH} 3.0-9.0$ for $1 \mathrm{~h}$. After treatment at $\mathrm{pH} 3.0$ for $1 \mathrm{~h}$, most of the antibacterial activity was lost. After treatment at $\mathrm{pH} 4.0$ 9.0 for $1 \mathrm{~h}$, there was no change in the antibacterial ac-

Table 1. Protein yields and MIC toward A. tumefaciens of various chromatographic fractions

Extract from $100 \mathrm{~g}$ dried mushroom

\begin{tabular}{lccc}
\hline Fraction & Yield $(\mathrm{mg})$ & MIC $(\mu \mathrm{M})$ & Purification fold \\
\hline Extract & 7230 & 15.8 & 1 \\
D1 & 1560 & - & - \\
D2 & 880 & - & - \\
D3 & 920 & 2.7 & 5.9 \\
D4 & 1480 & - & - \\
CM1 & 20 & - & - \\
CM2 & 40 & - & - \\
CM3 & 290 & 1.17 & 13.5 \\
CM4 & 70 & - & - \\
Q1 & 20 & - & - \\
Q2 & 90 & 0.5 & 31.5 \\
SU1 & 18 & 0.14 & 112.3 \\
SU2 & 15 & - & - \\
\hline
\end{tabular}

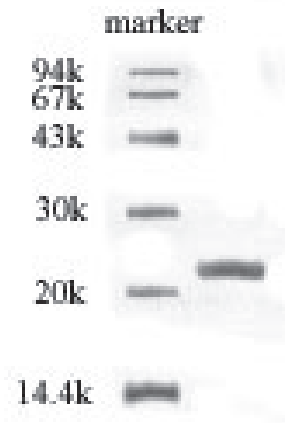

Figure 3. SDS/PAGE analysis of C. sinopica antibacterial protein Left: molecular mass markers. Right: fraction SU1 $(8.5 \mu \mathrm{g})$ from Superdex 75 column representing purified antibacterial protein.

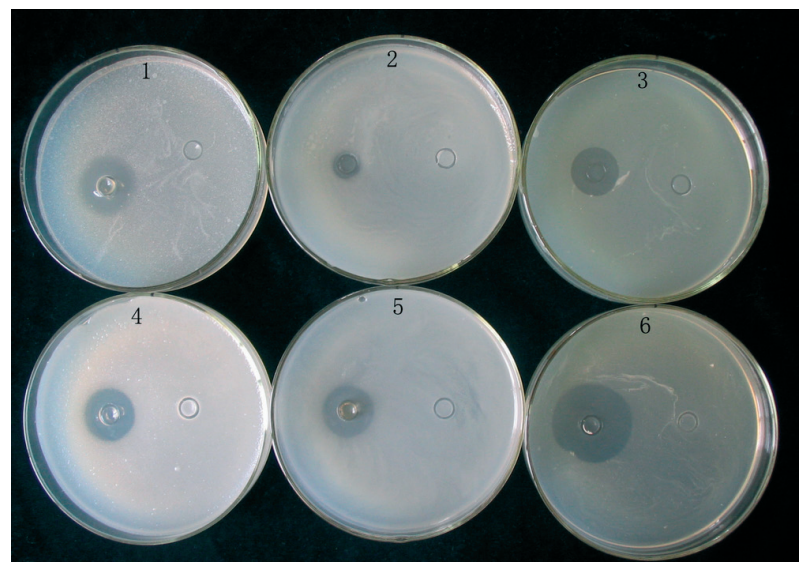

Figure 4. Photomicrograph showing antibacterial activity of isolated antibacterial protein toward various bacterial strains

The dosage of the antibacterial protein was $40 \mu \mathrm{g}$. Dishes 1, 2, 3, 4, 5 and 6 represent $A$. rhizogenes (NL24-2), A. rhizogenes (NL5-4), A. rhizogenes (MG 12-1), A. rhizogenes (HBT 6-1), A. vitis (MI3-2) and A. tumefaciens (MG10-1), respectively.

tivity. The data show that the antibacterial activity of the protein was stable over a fairly wide $\mathrm{pH}$ range.

\section{DISCUSSION}

Antibacterial peptides and proteins have great economic implications because they protect crops from the devastating damage brought about by bacterial infections. Antibacterial peptides/proteins which are different in physiological and biochemical characteristics such as molecular mass, MIC and antibacterial spectrum have been isolated from a variety of organisms. Kisugi et al. (1992) purified from Dolabella auricularia a large, 250-kDa antibacterial glycoprotein consisting of four subunits and showing both antibacterial and antineoplastic activities. Another large antibacterial protein of $190-\mathrm{kDa}$ was isolated from Ciona intestinalis. The protein consisted of more than one subunit (James et al., 1996). The sea hare Aplysia dectylomela produced a $60-\mathrm{kDa}$ monomeric antibacterial protein with hemagglutinating activity. It exerted activity against $S$. aureus with a MIC of $0.25 \mu \mathrm{M}$ (Melo et al., 2000). The silkworm Bombyx mori produced an antibacterial peptides with a higher activity against Gram-negative and -positive bacteria than cecropin B1, a major antibacterial peptide of $B$. mori. Its lethal concentration against $S$. aureus was less than $0.44 \mu \mathrm{M}$ (Hara \& Yamakawa, 1995a; 1995b). Ebran et al. (1999; 2000) 
Table 2. Comparison of $\mathrm{N}$-terminal sequence of $\mathrm{C}$. sinopica antibacterial protein with those of other antimicrobial proteins

\begin{tabular}{|c|c|c|c|c|}
\hline Name & Source & $\mathrm{N}$-terminal sequence & $\mathrm{Da}$ & Reference \\
\hline \multirow{8}{*}{ 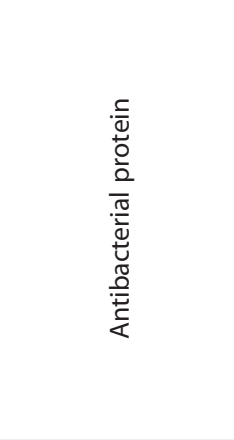 } & C. sinopica & SVQATVNGDKML & 44000 & This study \\
\hline & Marine bacterium & MNLKIHPSVGAXLGNRQM & 90000 & Barja et al., 1989 \\
\hline & Cordyceps sinensis & ALATQHGAP & 35000 & Hu et al., 2006 \\
\hline & Bullfrog & GVVKVSLRKGESLRARL & 1865 & Minn et al., 1998 \\
\hline & Bullfrog & IIKVPLKKFKSMRGVMRDHGIKAPVV & 3691 & Minn et al., 1998 \\
\hline & Scylla serrata & GQALNKLMPKIVSAIIYMVG & 10800 & Huang et al., 2006 \\
\hline & Bombyx mori-I & DLRFLYPRGKLPVPXPPPFNPKPITIDMGNRY & 5500 & $\begin{array}{l}\text { Hara \& Yamakawa, 1995a; } \\
\text { 1995b }\end{array}$ \\
\hline & Bombyx mori-Il & $\begin{array}{l}\text { AKIPIKAIKTVGKAVGKGLRAZNIASTANDVFN- } \\
\text { FLKPKKRKH }\end{array}$ & 4500 & $\begin{array}{l}\text { Hara \& Yamakawa, 1995a; } \\
\text { 1995b }\end{array}$ \\
\hline Trichogin & Tricholoma giganteum & QVHWPMF & 27000 & Guo et al., 2005 \\
\hline Alveolarin & Polyporus alveolaris & GVCDMADLA & 28000 & Wang et al., 2004 \\
\hline Eryngin & Pleurotus eryngii & ATRVVYCNRRSGSVVGGDDTVYYEG & 10000 & Wang \& Ng, 2004 \\
\hline Antifungal protein & Lyophyllum shimiji & AGTEIVTCYNAGTKVPRGPSAXGGAIDFFN & 20000 & Lam \& Ng, 2001a \\
\hline
\end{tabular}
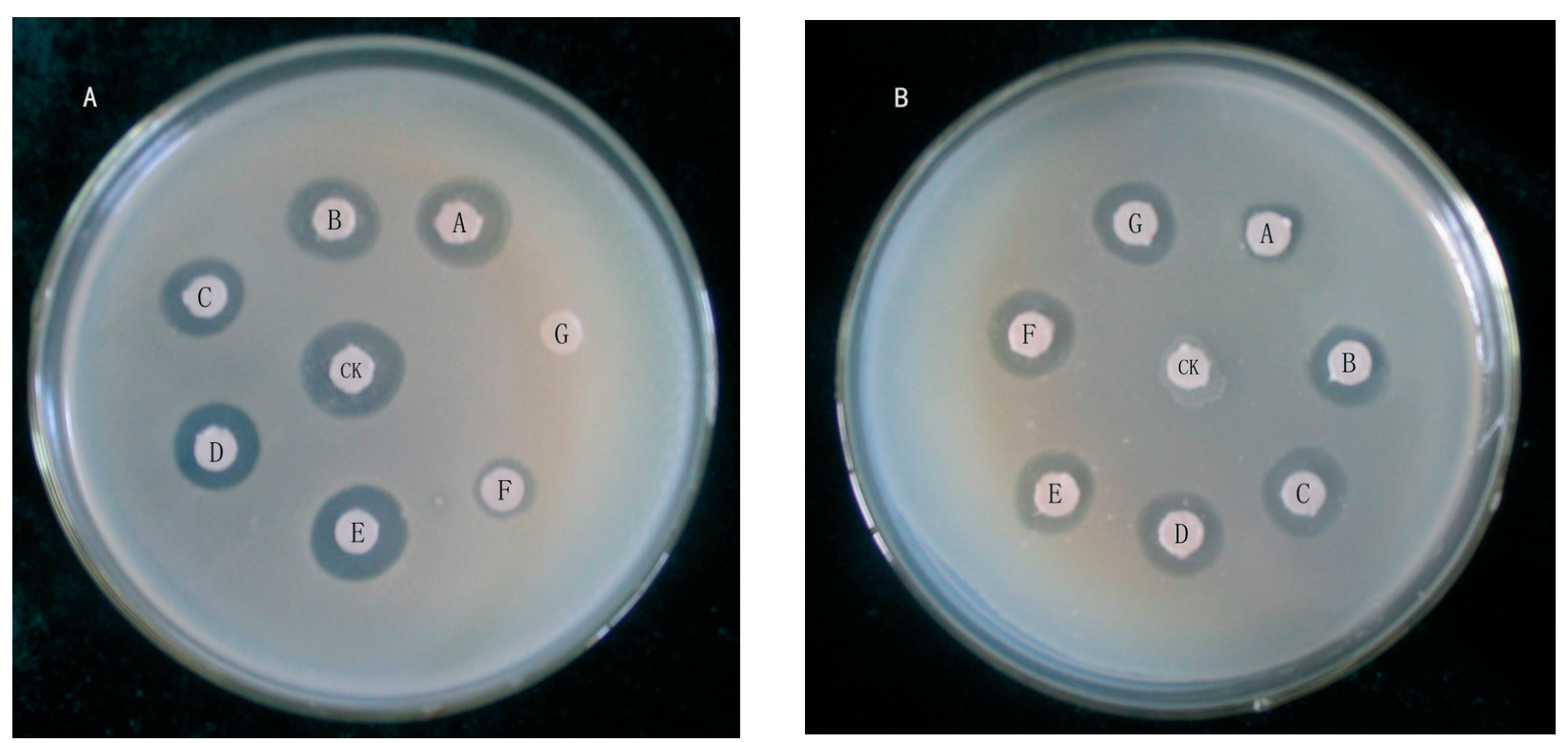

Figure 5. Effect of heat and $\mathrm{pH}$ treatments on the antibacterial activity of isolated antibacterial protein against $A$. tumefaciens

(A) Heat treatments (30 min). A $20 \mu \mathrm{g}$ sample of the protein was applied to each paper disk in sterile water. After treatment at $20^{\circ} \mathrm{C}$, $30^{\circ} \mathrm{C}, 40^{\circ} \mathrm{C}, 50-60^{\circ} \mathrm{C}, 70^{\circ} \mathrm{C}$ and $80^{\circ} \mathrm{C}$ for $30 \mathrm{~min}(\mathrm{~A}-\mathrm{G}),(\mathrm{CK})$ represents control incubated at $4{ }^{\circ} \mathrm{C}$ for $30 \mathrm{~min}$. (B) pH treatment $(1 \mathrm{~h})$. A 20 $\mu \mathrm{g}$ sample of the protein was applied to each paper disk in sterile water. After treatment at $\mathrm{pH} 3.0,4.0,5.0,6.0,7.0,8.0$ and 9.0 for $1 \mathrm{~h}$ $(A-G),(C K)$ represents control of sterile water.

reported antibacterial proteins with a molecular mass of $27-\mathrm{kDa}$ and $31-\mathrm{kDa}$ and activity against $P$. aeruginosa, P. fluorescens, Aeromonas byarophila and S. aureus from carp mucus. Their MIC ranged from $0.16 \mu \mathrm{M}$ to 4.8 $\mu \mathrm{M}$ against $S$. aureus. The bullfrog produced a $1865-\mathrm{Da}$ peptide and another 3691-Da one both with antibacterial activity. They exerted antibacterial activity against $B$. subtilis and E. coli with a MIC of 1.6-10.7 $\mu \mathrm{M}$ (Minn et al., 1998). A $35-\mathrm{kDa}$ antibacterial protein with a MIC of $14.3 \mu \mathrm{M}$ to $28.6 \mu \mathrm{M}$ was isolated from Cordyceps sinensis (Hu et al., 2006).

In this study, we describe the isolation and properties of an antibacterial protein with a molecular mass of 44 $\mathrm{kDa}$ from dried fruiting bodies of the wild mushroom C. sinopica. This protein displayed a strong antibacterial activity on Agrobacterium spp. and Xanthomonas spp., but there was no obvious inhibitory effect against fungi. A comparison of the $\mathrm{N}$-terminal sequence and the molecular mass of the $C$. sinopica antibacterial protein with the aforementioned antibacterial proteins reveals that they are distinctly different (Table 3). So it can be regarded as a novel antibacterial protein.

The behavior of the C. sinopica protein on the various ion exchange chromatographic media employed in the isolation procedure was different from that reported for other antimicrobial proteins. It was adsorbed on DEAE-cellulose whereas other antimicrobial proteins were not (Lam \& Ng, 2001a; Wang \& Ng, 2004; Wang et al., 2004; Guo et al., 2005), but they were all adsorbed on CM-cellulose. 
Table 3. Antimicrobial activity of $C$. sinopica antibacterial protein

\begin{tabular}{lc}
\hline Strain & MIC $(\mu \mathrm{M})$ \\
\hline A. rhizogenes (NL24-2) & 0.28 \\
A. rhizogenes (NL5-4) & 2.27 \\
A. rhizogenes (MG 12-1) & 0.28 \\
A. rhizogenes (HBT 6-1) & 0.28 \\
A. rhizogenes (SX073) & 0.14 \\
A. rhizogenes (NL12-2) & 0.28 \\
A. vitis (MI3-2) & 0.28 \\
A. vitis (MI23-1) & 1.14 \\
A. tumefaciens (MG10-1) & 0.14 \\
X. oryzae & 0.56 \\
$X$. malvacearum & 0.56 \\
\hline
\end{tabular}

The C. sinopica antibacterial protein was devoid of ribonuclease or lectin activities. This is important in view of the reports that some ribonucleases $(\mathrm{Ng} \&$ Wang, 2000; Wang \& Ng, 2000) and lectins (Broekaert et al., 1989; Gozia et al., 1995; Ye et al., 2001) exhibit antimicrobial activity.

In conclusion, our research demonstrated that $C$. sinopica fruiting bodies produce an antibacterial protein that shows a broad spectrum of activity against a number of plant pathogenic bacteria, including strains of the genera Agrobacterium and Xanthomonas. Its high potency and the broad spectrum of antibacterial activity suggest that the expression of its gene in transgenic plants may confer protection against bacterial pathogens.

Further work aims at the elucidation of the mechanism of action and cloning of the gene encoding the antibacterial protein for possible pratical application in the future.

\section{Acknowledgements}

This work was financially supported by National Grants of China (nyhyzx07-008, 2007BAD89B00 and 2010CB732202).

\section{REFERENCES}

Barja JL, Lemos ML, Toranzo A (1989) Purification and characterization of an antibacterial substance produced by a marine Alteromonas species. Antimicrob Agents Chemother 33: 1674-1679.

Broekaert WF, Van Parijs J, Leyns F, Joos H, Peumans WJ (1989) A chitin-binding lectin from stinging nettle rhizomes with antifungal properties. Science 245: 1100-1102.

Cammue BPA, Thevissen K, Hendriks M, Eggermont K, Goderis IJ, Proost P, Damme JV, Osborn RW, Guerbette F, Kader JC, Broekaert WF (1995) A potent antimicrobial protein from onion seeds showing sequence homology to plant lipid transfer proteins. Plant Physiol 109: 445-455.

Destoumieux D, Bulet P, Loew D, Dorsselaer AV, Rodriguez J, Bachère E (1997) Penaeidins, a new family of antimicrobial peptides isolated from the shrimp Penaeus vannamei (Decapoda). J Biol Chem 272: 398-406.

Ebran N, Julien S, Orange N, Saglio P, Lemaitra C, Molle G (1999) Pore-forming properties and antibacterial activity of proteins extracted from epidermal mucus of fish. Comp Biochem Physiol Part A 122: 181-189.

Ebran N, Julien S, Orange N, Auperin B, Molle G (2000) Isolation and characterization of novel glycoproteins from fish epidermal mucus: correlation between their pore-forming properties and their antibacterial activities. Biochim Biophys Acta 1467: 271-280.
Gozia O, Ciopraga J, Bentia T, Lungu M, Zamfirescu I, Tudor R, Roseamu A, Nitu F (1995) Antifungal properties of lectin and new chitinase from potato tuber. FEBS Lett 370: 245-249.

Guo YX, Wang HX, Ng TB (2005) Isolation of trichogin, an antifungal protein from fresh fruiting bodies of the edible mushroom Tricholoma giganteum. Peptides 26: 575-580.

Hara S, Yamakawa M (1995a) A novel antibacterial peptide family isolated from the silkworm Bombyx mori. Biochem J 310: 651-656.

Hara S, Yamakawa M (1995b) Moricin, a novel type of antibacterial peptide isolated from the silkworm Bombyx mori. I Biol Chem 270: 29923-29927.

Hirasawa M, Shouji N, Neta T, Fukushima K, Takada K (1999) Three kinds of antibacterial substances from Lentinus edodes (Berk.) Sing. (Shiitake, an edible mushroom). Int I Antimicrob Agents 11: 151-157.

Hu Z, Ye MQ, Xia LQ, Tu WJ, Li L, Zou GL (2006) Purification and characterization of an antibacterial protein from the cultured mycelia of Cordyceps sinensis. Wuban University Journal of Natural Sciences 3: 709-714.

Huynh QK, Bergmeyer JR, Zobel JF (1992) Isolation and characterization of a $22 \mathrm{kDa}$ protein with antifungal properties from maize seeds. Biochem Biophys Res Commun 182: 1-5.

James SG, Holmstrom C, Kjelleberg S (1996) Purification and characterization of a novel antibacterial protein from the marine bacterium D2. Appl Environ Microbiol 62: 2783-2788.

Jenssen H (2005) Anti herpes simplex virus activity of lactoferrin/ lactoferricin - an example of antiviral activity of antimicrobial protein/peptide. Cell Mol Life Sci 62: 3002-3013.

Krishnakumari V, Nagaraj R (1997) Antimicrobial and hemolytic activities of crabrolin, a 13-residue peptide from the venom of the European hornet, Vespa crabro, and its analogs. J Pept Res 50: 88-93.

Kisugi J, Ohye H, Kamiya H, Yamazaki M (1992) Biopolymers from marine invertebrates. XIII. Characterization of an antibacterial protein, dolabellanin A, from the albumen gland of the sea hare, Dolabella auricularia. Chem Pharm Bull 40: 1537-1539.

Lacadena J, Pozo AM, Gasset M, Patiño, B, Campos-Olivas R, Vázquez C, Martínez-Ruiz A, Mancheño JM, Oñaderra M, Gavilanesa JG (1995) Characterization of the antifungal protein secreted by the mould Aspergillus giganteus. Arch Biochem Biophys 324: 273-281.

Laemmli UK, Favre M (1973) Gel electrophoresis of proteins. J Mol Biol 80: 575-599.

Lam SK, Ng TB (2001a) First simultaneous isolation of a ribosome inactivating protein and an antifungal protein from a mushroom (Lyophyllum shimiji) together with evidence for synergism of their antifungal effects. Arch Biochem Biophys 393: 271-280.

Lam SK, Ng TB (2001b) Hypsin, A novel thermostable ribosome inactivating protein with antifungal and antiproliferative activities from fruiting bodies of the edible mushroom Hypsizigus marmoreus. Biochem Biophys Res Commun 285: 1071-1075.

Lam YW, Wang HX, Ng TB (2000) A robust cysteine-deficient chitinase-like antifungal protein from inner shoots of the edible chive Allium tuberosum. Biochem Biophys Res Commun 279: 74-80.

Lee DG, Shin SY, Maeng CY, Jin ZZ, Kim KL Hahm KS (1999) Isolation and characterization of a novel antifungal peptide from Aspergillus niger. Biochem Biophys Res Commun 263: 646-651.

Lehrer RI, Ganz T (1999) Antimicrobial peptides in mammalian and insect host defence. Curr Opinion Immunol 11: 23-27.

Lemaitre C, Orange N, Saglio P, Saint N, Gagnon J, Molle G (1996) Characterization and ion channel activities of novel antibacterial proteins from the skin mucosa of carp (Cyprinus carpio). Eur J Biochem 240: 143-149.

Lindequist U, Niedermeyer THJ, Jülich WD (2005) The pharmacological potential of mushrooms. eCAM 2: 285-299.

Longeon A, Peduzzi J, Barthélemy M, Corre S, Nicolas JL, Guyot M (2004) Purification and partial identification of novel antimicrobial protein from marine bacterium Pesudoalteromonas species strain X153. Mar Biotechno 6: 633-641.

Melo VMM, Duarte ABG, Carvalho AFFU, Siebra EA, Vasconcelos IM (2000) Purification of a novel antibacterial and haemagglutinating protein from the purple gland of the sea hare, Aplysia dactylomela Rang, 1828. Toxicon 38: 1415-1427.

Minn II, Kim HS, Kim SC (1998) Antimicrobial peptides derived from pepsinogens in the stomach of the bullfrog, Rana catesbeiana. Biochim Biophys Acta 1407: 31-39.

Mygind PH, Fischer RL, Schnorr KM, Hansen MT, Sönksen CP, Ludvigsen S, Raventós D, Buskov S, Christensen B, De Maria L, Taboureau O, Yaver D, Elvig-Jørgensen SG, Sørensen MV, Christensen BE, Kjaerulff S, Frimodt-Moller N, Lehrer RI, Zasloff M, Kristensen HH (2005) Plectasin is a peptide antibiotic with therapeutic potential from a saprophytic fungus. Nature 437: 975-980.

$\mathrm{Ng}$ TB, Wang HX (2000) Panaxagin, a new protein from Chinese ginseng possesses antifungal, antiviral, translation-inhibiting and ribosome inactivating activities. Life Sci 68: 739-749.

Steiner H, Hultmark D, Engström A, Bennich H, Boman HG (1981) Sequence and specificity of two antibacterial proteins involved in insect immunity. Nature 292: 246-248. 
Talas T (2004) Screening antimicrobial activities of basic protein fractions from dry and germinated wheat seeds. Biologia Plantarum 48: 583-588.

Torres-Larios A, Gurrola GB, Zamudio FZ, Possani LD (2000) Hadrurin, a new antimicrobial peptide from the venom of the scorpion Hadrurus åtecus. Eur J Biochem 267: 5023-5031.

Wang HX, Ng TB, Liu WK, Ooi VEC, Chang ST (1996) Isolation and characterization of two distinct lectins with antiproliferative activity from the cultured mycelia of the mushroom Tricholoma mongolicum. Int J Pept Protein Res 46: 508-513.

Wang HX, Ng TB (1999) Isolation of a new ribonuclease from fresh fruiting bodies of the straw mushroom. Biochem Biophys Res Commun 264: 714-718.

Wang HX, Ng TB (2000) Quinqueginsin, a novel protein with antihuman immunodeficiency virus, antifungal, ribonuclease and cell-free translation-inhibitory activities from American ginseng roots. Biochem Biophys Res Commun 269: 203-208.

Wang HX, Ng TB (2004) Eryngin, a novel antifungal peptide from fruiting bodies of the mushroom Pleurotus eryngii. Peptides 25: 1-5.

Wang HX, Ng TB, Liu QH (2004) Alveolarin, a novel antifungal polypeptide from the wild mushroom Polyporus alveolaris. Peptides 25: 693-696.

Weiler F, Schmitt MJ, Zygocin A (2003) Secreted antifungal toxin of the yeast Zygosaccharomyces bailii and its effect on sensitive fungal cells. FEMS Yeast Res 3: 69-76.

Ye XY, Ng TB, Tsang PWK, Wang J (2001) Isolation of a homodimeric lectin with antifungal and antiviral activities from red kidney bean (Phaseolus vulgaris). J Protein Chem 20: 367-375. 